\title{
CO-OPETITION TO PROMOTE GROWTH OF BATIK SMALL AND MEDIUM ENTERPRISES
}

\author{
Margani Pinasti* \\ Universitas Jenderal Soedirman \\ Wiwiek Rabiatul Adawiyah \\ Universitas Jenderal Soedirman
}

\begin{abstract}
Co-opetition is cooperation and also the competition between businesses in the same industry or in other words between competitors. The phenomenon of co-opetition, which is also called 'sleeping with the enemy', is becoming increasingly important with the wider of global competition. The purpose of research presented in this paper is to analyze the co-opetition strategy among small and medium industries. This research was conducted in the form of case studies of small and medium batik industries in the region of Central Java, Indonesia. The right co-opetition strategy would promote growth and strengthen the sustainability of Central Java batik SMEs to face global competition.The research approach applied is action research. The location of this research is in six districts in Central Java, namely Banyumas, Cilacap, Purbalingga, Banjarnegara, Kebumen and Wonosobo. In those six districts, there are batik SMEs that have the potential to grow rapidly. The results of this study indicate that batik SMEs in the region of Central Java agreed to collaborate in the form of the Central Java Batik Society 'DjamurDwipa'. The batik SME entrepreneurs in Central Java realize that they are partners in the Society and they are also competitors engaged in the same industry. For small and medium scale entrepreneurs, their collaboration is expected to increase their capability, create and capture value, get the benefit of networking. The Central Java Batik Society 'DjamurDwipa' in this study becomes one of the case models of co-opetition among small and medium industries. Review of the co-opetition among small and medium industries in this study indicate that the competitors do not always have a negative impact. Collaboration with competitors, namely co-opetition, could be able to create a synergy that can encourage the growth of small and medium industries.
\end{abstract}

Keywords: Co-opetition; Colaboration; Competitor; Batik; Small Medium Enterprises.

\section{INTRODUCTION}

Co-opetition is a phenomenon in which cooperation and competition among businesses coexist. This occurs because the cooperating companies are in the same industry (Gnyawali et al., 2006; Chen, 2008; Luo, 2007; Ketchen et al., 2004). This phenomenon

\footnotetext{
"Corresponding author: Margani Pinasti, Faculty of Economics and Business, Universitas Jenderal Soedirman, Jl. HR Boenyamin, Purwokerto, Central Java, Indonesia. E-mail address: margani.pinasti@yahoo.co.id.
} 
has actually been going on long enough. Gnyawali and Park (2009) stated that more than fifty percent of the strategic alliance and cooperation occur between companies that are in the same industry or among competitors. The development of the expanding global business, for example Asean Economic Community, make co-opetition phenomenon is becoming increasingly urgent.

Batik small and medium industry is an industry that is experiencing rapid development and has great potential to be developed at this time. Batik is a technique of wax-resist dyeing applied to whole cloth, or cloth made using this technique. Batik is made either by drawing dots and lines of the resist with a spouted tool called a canting, or by printing the resist with a copper stamp called a cap. The applied wax resists dyes and therefore allows the artisan to color selectively by soaking the cloth in one color, removing the wax with boiling water, and repeating if multiple colors are desired. The batik of Indonesia has been designated by UNESCO as Masterpieces of the Oral and Intangible Heritage of Humanity since 2nd October 2009.

The Indonesian batik industry experience rapid growth in recent years. Based on data of Directorate General of SME, The Ministry of Industry of the Republic of Indonesia, in 2015 there were 47,755 batik SMEs in Indonesia. Batik industry contribute to employment by involving more than 200,000 workers. More than fifty percent of batik SMEs located in Central Java.

In Indonesia, Central Java is one of the areas of batik small and medium enterprises (SMEs) center which has great potential. Beside the Pekalongan and Solo batik, in the southern region of the Central Java province, there are centers of batik industry which has a distinctive and attractive patterns. This southern region of the Central Java province covers six districts, namely Banyumas, Cilacap, Purbalingga, Banjarnegara, Kebumen and Wonosobo. Batik produced from this region even attract customers from abroad. Nevertheless, the batik industry in this region facing various challenges. Small and medium size industries resulted in limited production capacity. When there is a large-scale orders, the batik entrepreneurs find it difficult to fulfill. In addition, the limitations of this scale also lead marketing limitations, limited supply of raw materials, limited technology development and limited communication with the government as an adviser and policy makers. This research focus on these six districts in Central Java because of the great potential, yet facing various problems.

To overcome obstacles and to encourage the development of batik SMEs, co-opetition between batik entrepreneurs is required. The literature on co-opetition stated that the need for co-opetition is greater in the context of small and medium enterprises (Gnyawali and Park, 2009). Morris et al. (2007) suggest small and medium enterprises to collaborate with their competitors so they can create economies of scale, mitigate risk, and leverage the resources together. The entrepreneurs in the same industry tend to facing same challenges and have the resources and capabilities that are relevant to each other. Small and medium enterprises can effectively deal with large-scale competitors if they collaborate with each other. 
Co-opetition is unique to each industry and geographic region. Industry characteristics and the characteristics of the geographical area affect the pattern of co-opetition between entrepreneurs in it. Batik small and medium enterprises in the southern region of the province of Central Java, Indonesia, also requires co-opetition to be able to overcome various obstacles and encourage their growth. This paper aims to analyze the strategy of co-opetition between batik small and medium enterprises with a case study on batik SMEs in the southern region of the province of Central Java, Indonesia.

Analysis of the co-opetition strategy that can encourage the growth of small and medium industries have several important contributions. The pattern of coopetition between batik small and medium enterprises as a result of this research can be a model for the development of other industries as well as for other areas to facing a stronger competitor. Theoretically, the results of this research can stimulate and develop research on co-opetition in the context of small and medium industries. The concept of co-opetition for small and medium industries is still an emerging concept that requires further study. For the regulators who determine the policy, the results of this research also contributed to the development of batik small and medium enterprises through co-opetition.

\section{LITERATURE REVIEW}

\subsection{The Concept and Importance of Co-opetition}

Co-opetition means simultaneously collaborate and compete with the same partners at the same time (Gnyawali and Park, 2011; Yami et al., 2011; Czakon et al., 2014; Rusko, 2011). In a broader context, the concept of co-opetition include collaboration and competition with the same competitors but at different times. Broad concept of coopetition also includes collaborations with some competitors to build up the strength facing another competitor. One form of co-opetition is to make the competitors as a subcontractor at the time the business has full production capacity. Small and medium enterprises can form alliances with competitors to handle large projects. Chein and Peng (2005) in their research on companies in the simulator industries in Taiwan, stated that these companies compete with one another at the time of project bidding, and after they won the bid of the project, they collaborate and work together to fulfill the project.

Gnyawali and Park (2009) stated that in the future, small and medium industries will be more likely to engage in co-opetition, which collaborate and compete at the same time, with the same partners, both competitors of small and medium industries as well as larger competitors. Due to the changing dynamics of today, collaboration and cooperation relations among small and medium industries are expected to be more co-opetitive. Networking cooperation among small and medium industries will involve direct competitors in the same industry, or some existing collaborators turned into competitors. 
Morris et al. (2007) stated that the relations and cooperation networks play an important role in the development of small and medium industries. Cooperation network can help small and medium industries in facing stronger competitors, facilitating entry into new markets, and provide access to external resources. Merrifield (2007) even explicitly states that the collaboration between small and medium enterprises is very important and crucial to the survival of SMEs. Ritala (2011) stated that at firm level there is growing evidence that coopetition fosters innovativeness and technology development.

Previous research demonstrated the importance of co-opetition for small and medium industries in the perspective of creating economies of scale. Gomes-Casseres (1997) research for small industries in the field of computer showed that small industries can survive facing great players through the establishment of a constellation consisting of several small businesses in the same field. Eikebrokk and Olsen (2005) also showed empirically that co-opetition in e-business encourages SMEs to improve the novelty of their business and to combine complementary strengths in products and technologies. Even some research suggests that the tendency of SMEs to co-opetition has effect on their financial performance. Overall, these previous research stated that cooperation with competitors is essential and become a key strategy for the development of small and medium industries.

\subsection{Theoretical Framework for Co-opetition}

There are three theories that could explain the motivation and the impact of co-opetition for small and medium industries. These theories are the resource-based view (RBV), game theory, and network theory.

The resource-based view (RBV) suggests that firms seek to capitalize on and increase their capabilities and endowments. Influential literature on RBV suggests that a firm's ability to attain and maintain a profitable market position depends on its ability to deploy and combine resources, including human, physical, and reputational resources. Recently, the RBV has been broadened to account for external resources that are available to firms through their network relationships, suggesting that firms can combine internal and external resources to competitive advantage. According to the RBV, when facing resource limitations, managers are attracted to cooperative arrangements to overcome such constraints (Meiseberg and Ehrmann, 2013). Based on the RBV framework, Lado et al. (1997) propose a syncretic model, arguing that "success in today's business world often requires that firms adopt both competitive and cooperative strategies simultaneously." The best partner for a firm in a strategic alliance is sometimes one of its strong competitors. Gnyawali and Park (2009) suggest that the dynamic capability-based perspective, focusing on how asset stocks are accumulated, mobilized, and deployed to generate a sustainable competitive advantage, provides a basis upon which to examine the accumulation of resource stocks through both competition and collaboration. 
The game theory is the second theory that can explain the phenomenon of coopetition among small and medium industries. Game theory explains a win-win approach in co-opetition through creating and capturing value. Gnyawali and Park (2009) illustrated how a firm can use game theory to achieve positive-sum gains by changing the players, the rules of the game, and the scope of the game. This suggests that game theory does not apply purely competitive perspective. Cairo (2006) says that the co-opetition in business approach relies on the premise that companies' activities involve two central elements - creating value and capturing value. Elements of creating value associated with the establishment of new value or enlargement of the existing value. While capturing value element associated with 'dividing up of the pie'. Both of these elements encourage businesses to have a new perspective. A win-win approach is the most effective way to create greater value, and thus be able to obtain 'a bigger slice'. Small and medium industries should seek opportunities to create new values together, achieve synergies, and may eventually acquire 'a positive sum game'.

The third theory adopted in this research to explain the phenomenon of co-opetition is the network theory. Perspective of network theory helps explain and articulate how to access and expand the knowledge and resources outside the company, how to leverage these resources, as well as the types of relationships that appropriate. Networking cooperation with competitors will provide an opportunity for companies to learn about their competitor partners (and also partners of their partners indirectly) and provide access to resources from competitor partners. Gnyawali and Madhavan (2001) state that there are three types of resources flow among partners of cooperation network, i.e. information flows, asset flows, and status flows. Cooperation networks allow mutual access to the partner resources. This enables better-positioned firms to more swiftly access network-based resources and use them to aggressively pursue competitive opportunities. Therefore, networks that managed properly can create and enlarge the value.

\section{RESEARCH METHODS}

\subsection{Research Approach}

This study is an action research. In action research, the researchers describe, interpret and explain a social situation at the same time to make changes or interventions with the goal of improvement or participation. Davison et al. (2004) mentions action research as a research method, founded on the assumption that the theory and practice can be integrated with the learning of the results of the planned intervention after a detailed diagnosis to problem context. Action research is an activity or corrective action which planning, implementation, and evaluation is done in a systematic way so that the validity and reliability reached a stage of research.

Action research approach is deemed appropriate to be applied in this study, because the action research aimed to contribute to the solution of practical problems in the immediate problematic situation. Action research also contributes to the achievement of 
the objectives of social sciences through a joint collaboration in conducting a mutually acceptable ethical work.

\subsection{Research Location}

The social context that became the focus of this research is batik small and medium enterprises in the southern region of the province of Central Java, Indonesia. There are six districts that became home to batik small and medium enterprises in this study, namely Banyumas, Cilacap, Purbalingga, Banjarnegara, Kebumen and Wonosobo. These six districts are located within a distance of about $90 \mathrm{~km}$ radius of the Universitas Jenderal Soedirman, the institution of the researcher. Key informants in this study are the batik entrepreneurs who have an important role in these districts.

\section{RESULT AND DISCUSSION}

\subsection{Description of Batik Small and Medium Enterprises in the Southern Region of the Province of Central Java, Indonesia}

In the southern region of the province of Central Java, Indonesia, there are many industrial centers of batik with a small to medium scale. Batik industry in this region has a different characteristic with Solo or Yogyakarta batik and Pekalongan batik. Batik is produced mostly done with the process of drawing with canting (batik tulis) and with stamp (batik cap). Batik motif in this region raised characteristic of flora and fauna around, for example manggaran motif (flower of coconut tree), lumbu leaf motif, carica fruit motif, eagle motif, and marine animals motif. There is also a classic batik motifs which are the ancestral heritage.

Figure 1: Location of Batik SMEs in the Southern Region of Central Java Province, Indonesia

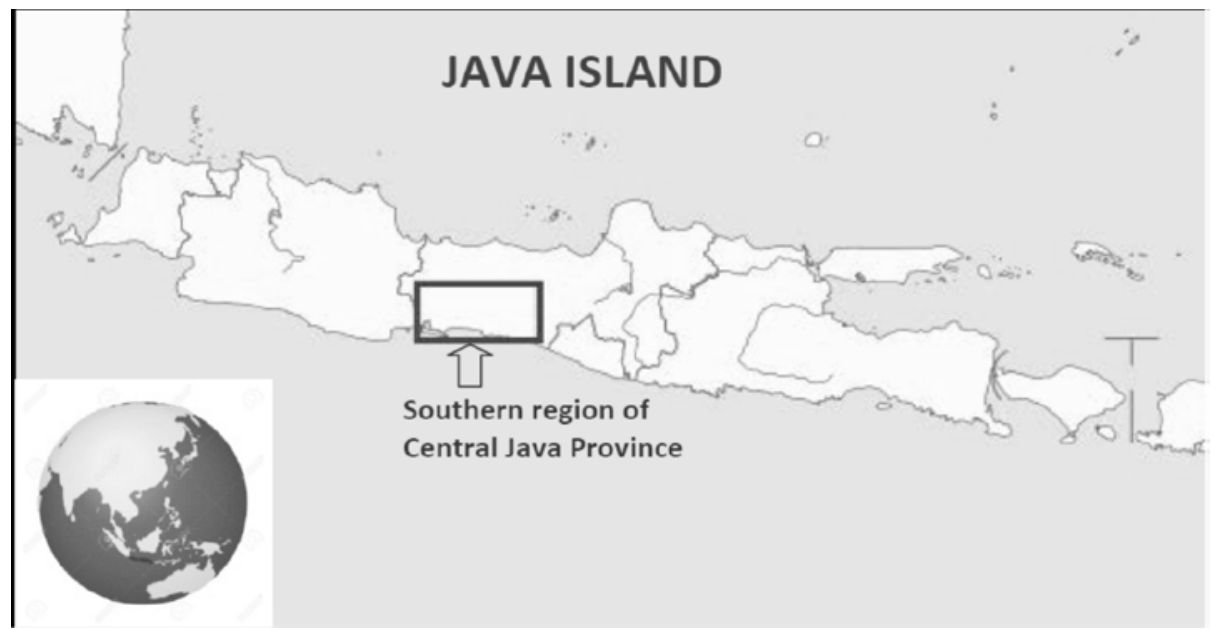


Batik products from the southern region of Central Java province is well known nationally, even internationally known also. One of batik entrepreneurs from Cilacap District, which also became informants in this study, has exhibited its batik products in several international exhibitions. This suggests that the batik SMEs in the region have good market opportunities and enormous potential for growth.

Batik industry in the southern region of Central Java province also have an impact on the surrounding community employment. Batik industry is a creative economy industry and has a great role as leverage pro-people economic growth, as well as contributing to job creation and improvement of people's income. Based on data from the Department of Industry and Trade of Banyumas, Cilacap, Purbalingga, Banjarnegara, Kebumen and Wonosobo, in every district there are hundreds of batik craftsmen. This suggests an important contribution of batik industries to the growth of the national economy.

However, Pinasti et al. (2013) research showed that the batik SMEs in the southern region of Central Java face many problems that can inhibit the growth of the industry. The raw material is obtained from fairly remote location, resulting in high production costs and no guarantee of availability of raw materials. There are limited managerial capabilities and limitations of technological mastery. Batik technology applied is simplified or traditional. Advanced technologies, such as electric canting, batik fractal, have not been widely implemented. Coloring technology and industrial waste water treatment is also not well understood. The market of mostly batik SMEs are local or regional, only a few batik SMEs are able to penetrate the national market and very few batik SMEs are already exporting. Capital largely derived from its own capital. Partnership with major industry has not been done. Assistance from government agencies not well coordinated, due to the absence of integrated development programs of batik SMEs.

\subsection{Co-opetition among Batik SMEsin the Southern Region of the Province of Central Java}

Based on in-depth interviews and focus group discussions with batik entrepreneurs and local goverments, researchers obtained information of the need for collaboration among batik entrepreneurs in the southern region of Central Java province. Collaboration with entrepreneurs in the same industry shows co-opetition. Batik entrepreneurs are aware that their collaboration partners are also their competitors.

Willingness to co-opetition based on the need to expand the market and facing larger competitors. Asean Economic Community (AEC) reinforces the importance of co-opetition, especially to deal with competitors from abroad. For small and medium enterprises, to face the global market such as the ASEAN Economic Community, it is necessary to collaborate with various parties, including competitors in the same industry. Another reason for the importance of co-opetition proposed by batik entrepreneurs in the southern region of Central Java province are able to keep each other informed, facilitate access to raw materials and other resources as well as to 
preserve batik. Co-opetition is also expected to overcome the various problems faced by the batik SMEs in the southern region of Central Java province.

Based on the need to collaborate with competitors in the same industry, then on May 7th 2014 an agreement was reached between batik entrepreneurs in six districts in the southern region of Central Java to form a Central Java Batik Society 'Djamur Dwipa' (Paguyuban Batik Djamur Dwipa Jawa Tengah). This association was passed by notarial deed. As a form of co-opetition, this community has a vision and mission agreed, and also has management and activities design. The benefits of coopetition in the community of Central Java Batik Society 'Djamur Dwipa' are stated in the design of the following activities: sharing provision or supply of raw materials, bulk purchase; organizing training to improve skills and mastery of technology; development of network marketing, sub-contract for large quantities orders; increasing funding opportunities; development of partnership among SMEs and between SMEs and large industry; and information service about batik. The design of these activities covered by notarial deed of association establishment.

The batik SME entrepreneurs in Central Java realize that they are partners in the Society and they are also competitors engaged in the same industry. For small and medium scale entrepreneurs, their collaboration is expected to strengthen their position in the face of larger competitors. Limitations of production capacity also encourage collaboration among Central Java batik SME entrepreneurs. They can make others batik SME entrepreneurs as a sub-contractor when there is over-capacity as a result of a large amount of orders. Co-opetition strength is also used to get in touch with the regulator (in this case the local government) in order to get support. The synergy that occurs in coopetition among batik SMEs in Central Java is also possible to open a broader business opportunities.

\subsection{Co-opetition to Promote Growth of Batik SMEsin the Southern Region of the Province of Central Java}

\section{(a) Co-opetition to Enhance Capabilities}

One form of co-opetition between batik SMEs in the southern region of Central Java are sub-contract between the competitors partner when getting orders that exceed production capacity. This forms of co-opetition is very possible to do because they are familiar with the motif of their competitors partner. This is due to the proximity of the geographical area and the similarity of their batik motif pattern. The results of in-depth interviews with batik entrepreneurs stated that this co-opetition can be done while retaining control over product quality subcontracted.

Co-opetition in the form of sub-contract conforms to the resource based view (RBV). Meiseberg and Ehrmann (2013) states that according to the RBV, when facing resource limitations, managers are attracted to cooperative arrangements to overcome such constraints. Orders in very large numbers ever faced by the batik entrepreneurs in the 
southern region of Central Java. The small to medium scale business makes them have limited production capacity. Without co-opetition, then orders over capacity can not be fulfilled. This can have a negative effect on the growth of batik industries. Lado et al. (1997) stated that 'the best partner for a firm in a strategic alliance is sometimes one of its strong competitors.' With regard to sub-contract, it is very appropriate, because the competitors know the production process, motif and quality desired. Thus, the strategy of collaboration with competitors (co-opetition) can improve the capability of the company, and in turn encourage the growth of the industry.

Another form of co-opetition that also deals with RBV and increasing resources capabilities is collaboration in raw material supply. In the southern region of Central Java, there is no textile industries, so that the raw material of batik must be purchased from fairly far location. In terms of supply of raw materials, the coopetition strategies that can be done are supply in bulk in large quantities so that the cost of raw materials become cheaper and more efficient, exchange information about the supply of raw materials, the formation of batik cooperatives for the supply of raw material, and mutual supply if there is a necessary requirement. These coopetition strategies aims to maintain continuity of availability of raw materials which are vital resources in the batik industry. This co-opetition again supports the statement that 'the best partner for a firm in a strategic alliance is sometimes one of its strong competitors', because of the similarity of raw materials needed.

\section{(b)}

\section{Co-opetition to Create and Enlarge Value}

Game theory explains a win-win approach in co-opetition through creating and capturing value. Batik small and medium industries in the southern region of Central Java jointly seek opportunities to create new values, achieve synergies, and may eventually acquire 'a positive sum game'. One form of co-opetition between batik SMEs in the southern region of Central Java to create and enlarge value is through a joint marketing strategy. This can be done with mutual marketing, market information sharing and joint exhibitions. Batik entrepreneurs in the southern region of Central Java agreed to open a joint web of Central Java Batik Society Djamur Dwipa to introduce their batik products and educate the public about the development of batik.

The results of in-depth interviews and focus group discussion also shows that coopetition between batik entrepreneurs are intended to protect the price and facing major competitors. Without co-opetition, can occur 'price war' and 'strategy to lower quality' which is unfair competition. Co-opetition between batik SMEs in the field of marketing also can strengthen their position in facing larger competitors.

Another forms of co-opetition that can also create and enlarge value are joint training, sharing of knowledge and experience in the batik process, cooperation in craftmen regeneration, and collaboration with competent institutions of batik training. In the field of technological mastery, collaboration that can be done are exchange information about batik technology, sharing of technological mastery of batik process, and the provision of batik tools (canting, stamp, etc.). 


\section{(c) Co-opetition to Build Networking Power}

Central Java Batik Society 'Djamur Dwipa' is a cooperation network among batik entrepreneurs in the southern region of Central Java. This cooperation network with competitors will strengthen the power and influence of batik entrepreneurs against the government and society. Without co-opetition, the influence of batik SMEs toward government policy becomes insignificant. Co-opetition in the Society's cooperation networks can be used to obtain the support of the government, especially local government. Supports that can be obtained are government policies that encourage the widespread use of batik products, policies to protect batik motif, and policies of mentoring programs aimed at encouraging the growth of the batik industries.

\section{CONCLUSION}

Collaboration with competitors, namely co-opetition, could be able to create a synergy that can encourage the growth of small and medium industries. Batik entrepreneurs in the southern region of Central Java realize the importance of co-opetition strategy. Co-opetition is necessary to expand the market and facing larger competitors. Coopetition is considered important because through it, batik entrepreneurs are able to provide information each other, facilitate access to raw materials and other resources as well as to preserve batik. Co-opetition is also expected to overcome the various problems faced by batik SMEs in the southern region of Central Java. To realize the coopetition, batik entrepreneurs in the southern region of Central Java, agreed to form the Central Java Batik Society 'Djamur Dwipa', which was passed by notarial deed. The batik SME entrepreneurs in Central Java realize that they are partners in the Society and they are also competitors engaged in the same industry.

Co-opetition can promote the growth of batik SMEs by increasing capability, creating value, and building power through cooperation network. Increased capability can be done through subcontracting strategy with competitors when getting orders that exceed the capacity, and also through collaboration of raw material supply. Value creation and enlargement can be done through joint marketing strategy and price protection to strengthen the position of facing larger competitors. Co-opetition also strengthen the power and influence of batik entrepreneurs against the government and society. Coopetition support the statement 'the best partner for a firm in a strategic alliance is sometimes one of its strong competitors.'

\section{ACKNOWLEDGEMENTS}

We would like to acknowledge the support and cooperation of batik entrepreneurs in the southern region of Central Java province. We also acknowledge the support of our home institution, Universitas Jenderal Soedirman, Purwokerto, Indonesia. 


\section{REFERENCES}

Cairo, R. (2006). Co-opetition and Strategic Business Alliances in Telecommunications: The Case of BT, Deutsch Telekom and Telefonica Espana. The Business Review, 5(2), 147-154.

Chen, M. J. (2008). Reconceptualizing the Competition-Cooperation Relationship: A Transparadox Perpective. Journal of Management Inquiry, 17, 288-305.

Chien, T. H., \& Peng, T. J. (2005). Competition and Cooperation Intensity in a Network - A Case Study in Taiwan Simulator Industry. Journal of American Academy of Business, 7(2), 150-155.

Czakon, W., Mucha-Kuś, K., \& Rogalski, M. (2014). Coopetition Research Landscape A Systematic Literature Review 1997-2010. Journal of Economics and Management, 17, 122-150

Davison, R. M., Martinsons, M. G., \& Kock, N. (2004). Principles of Canonical Action Research. Information Systems Journal, 14(1), 65-86.

Eikebrokk, T. R., \& Olsen, D. H. (2005). Co-opetition and e-Business Success in SMEs: An Empirical Investigation of European SMEs. Proceedings of the 38th Annual Hawaii International Conference. Big Island, Hawaii.

Gnyawali, D. R., \& Park, B. (2009). Co-opetition and Technological Innovation in Small and Medium-Sized Enterprises: A Multilevel Conceptual Model. Journal of Small Business Management, 47(3), 308-330.

Gnyawali, D. R., \& Park, B. (2011). Co-opetition between Giants: Collaboration with Competitors for Technological Innovation. Research Policy, 40(5), 650-663

Gnyawali, D. R., He, J., \& Madhavan, R. (2006). Impact of Co-opetition on Firm Behavior: An Empirical Examination. Journal of Management, 32(4), 507-530.

Gomes-Casseres, B. (1997). Alliance Strategies of Small Firms. Small Business Economics, 9(1), 33-44.

Gynawali, D. R., \& Madhavan, R. (2001). Cooperative Networks and Competitive Dynamics: A Structural Embeddedness Perspective. Academy of Management Review, 26(3), 431-445.

Ketchen, D. J., Snow, C. C., \& Hoover, V. L. (2004). Research on Competitive Dynamics: Recent Accomplishments and Future Challenges. Journal of Management, 30(6), 779-804.

Lado, A. A., Boyd, N. G., \& Hanlon, S. C. (1997). Competition, Cooperation, and the Search for Economic Rents: A Syncretic Model. Academy of Management Review, 22(1), 110-141.

Luo, Y. (2007). A Coopetition Perspective of Global Competition. Journal of World Business, 42(2), 129-144.

Meiseberg, B., \& Ehrmann, T. (2013). Tendency to Network of Small and Mediumsized Enterprises: Combining Organizational Economics and Resource-based Perspectives. Managerial and Decision Economics, 34(3-5), 283-300.

Merrifield, D. B. (2007). Strategic Collaborations - Essence of Survival. Research Technology Management, 50(2), 10-14. 
Morris, M. H., Kocak, A., \& Ozer, A. (2007). Coopetition as a Small Business Strategy: Implications for Performance. Journal of Small Business Strategy, 18(1), 35-55.

Pinasti, M., Setyorini, C. T., \& Rokhayati, H. (2013). Cooperative among Small Medium Enterprises and Coordination among PublicAgencies as A Social Model to Reinforce An Industry Cluster: A Case Study of Batik Cluster in South-Central Java, Indonesia. Paper presented at The 2nd International Conference on Rural Development and Entrepreneurship (ICORE 2013).

Ritala, P. (2011). Coopetition Strategy - When Is It Successful? Empirical Evidence on Innovation and Market Performance. British Journal of Management, 23(3), 307-324.

Rusko, R. (2011). Exploring the Concept of Coopetition: A Typology for the Strategic Moves of the Finnish Forest Industry. Industrial Marketing Management, 40(2), 311-320.

Yami S., Castaldo S., Dagnino G. B., \& Le Roy F. (2011). Coopetition - Winning Strategies for the 21st Century. Cheltenham, UK: Edward Elgar Publishing Ltd. 